\title{
Kegiatan Hubungan Media pada Direktorat Komunikasi Publik di Universitas Padjadjaran
}

\author{
Elvira Juwita Saraswati ${ }^{1}$, Rosnandar Romli ${ }^{2}$, dan Aat Ruchiat Nugraha ${ }^{3}$ \\ ${ }^{1} \mathrm{PT}$. Taspen (Persero) \\ ${ }^{2,3}$ Universitas Padjadjaran
}

\begin{abstract}
ABSTRAK
Kegiatan media relations menjadi salah satu penentu dalamkeberhasilan Unpad dalammencapai misinya untuk menjadi transformative university oleh karena itu, dibutuhkan sebuah strategi komunikasi dan pendekatan khusus kepada media massa untuk mencapai tujuan tersebut. Adapun strategi media relations yang dilakukan melalui pola hubungan kegiatan kehumasan dalam bentuk two ways asymmetrical. Penelitian ini menjelaskan tahapan strategi komunikasi yang dilakukan Unpad terdiri dari tahap perumusan kebutuhan publikasi Unpad dalam upaya menjalin hubungan baik dengan media massa, tahap perencanaan, tahap implementasi dan tahap evaluasi pada program Unpad Merespon dengan referensi. Hasil penelitian menunjukkan bahwa melalui pendekatan komunikasi interpersonal yang dilakukan secara konsisten dan layanan informasi yang responsif dari pejabat Humas kepada wartawan mampu menciptakan hubungan media yang saling membutuhkan dan menguntungkan. Hubungan tersebut berjalan informal dengan memposisikan media massa sebagai bagian yang aktif dalam memberikan informasi kebutuhan berita yang dibutuhkan publik kepada Unpad serta dipengaruhi oleh figure public relation officer Unpad. Sehingga program Unpad Merespon, menjadi wadah yang mempertemukan kebutuhan media akan informasi yang sesuai dengan karakter media massa itu sendiri dan Unpad mendapat publikasi kepakaran para dosen yang menjadi narasumber dalam menaggapi persoalan yang kekinian di masyarakat. Hasil tulisan dari media massa tersebut bervariasi dan konsisten menempatkan akademisi Unpad sebagai sumber informasi yang kemudian dimonitoring untuk melihat responsifitas dari masyarakat terhadap eksistensi Unpad. Penelitian ini menggunakan metode deskriptif, dengan jenis data kualitatif melalui pengumpulan data dengan cara wawancara mendalam kepada sembilan orang narasumber, terdiri dari tujuh orang staff dan pimpinan Direktorat Tata Kelola dan Komunikasi Publik, serta dua orang jurnalis dari harian Bisnis Indonesia dan Pikiran Rakyat.
\end{abstract}

Kata-kata Kunci:Citra; hubungan media; twoways asymmetrical; proses PR; program PR

\section{Media Relationships in Public Communication Directorate of Universitas Padjadjaran}

\section{ABSTRACT}

Media relations activities becomes one of determining the success of Padjadjaran University in achieving its mission to become a transformative university therefore, needs a communication strategy and special approach to the mass media to reach these goals. The media relations strategy that is conducted through the pattern of relationships public relations activities in two ways asymmetrical shape. These research describe the process of Unpad communication strategy include stage of formulation the requirement of publicantion in effort to establish good relationship with mass media. Planning stage, implementation stage, and evaluation stage of Unpad Merespon program. The results showed that through interpersonal communication approach and responsive information service of $P R$ officials told reporters able to create media relations are interdependent and profitable. The relationship done informally, consitent and also affected by the public relation officer. So that the program "Unpad Respond", a forum that brings together the media needs to be information in accordance with the character of the mass media itself and Padjadjaran University professors will be publishing expertise, the informant in responding to contemporary issues in society. The article wrote by mass media are variaty and put the Unpad academics as the interviewess contiually do the monitoring trough the resposivity of public affect the existence of Unpad. This research uses descriptive method with qualitative data through data collection by depth interviews with nine speakers, consisting of seven staff and leaders of the directorate governance and public communication, as well as two journalists from the newspaper Bisnis Indonesia and Mind.

Keywords: Image; media relations;two ways asymmetrical; pr process; pr program

Korespondensi: Elvira Juwita Saraswati, S.Sos.PT. taspen (Persero). Jl. Letjen Suprapto No.45 Cempaka Putih, Jakarta Pusat 10520.Email: elvirajuwutasaraswati@taspen.co.id 


\section{PENDAHULUAN}

Hubungan media merupakan salah satu tugas Public Relations dalam upaya menciptakan kondisi kerja yang kondusif melalui pemberitaan positif di media massa. Memiliki hubungan media yang baik, akan memberikan dampak positif bagi institusi dalam mencapai citra positif dan meningkatkan kredibilitas dimata stakeholder dan kompetitor. Melalui hubungan media seorang profesional Public Relations suatu lembaga/organisasi dapat memanfaatkan media sebagai alat dan strategi dalam membangun hubungan dengan pihak media massa (Hidayat, 2014). Citra dan kredibiltas merupakan salah satu tools dalam mencapai visi dan misi. Dalam kesehariannya kegiatan PR sebesar 20\% adalah kegiatan hubungan media. Sehingga penting bagi sebuah instansi untuk memiliki strategi komunikasi kepada media massa. Sebab strategi komunikasi merupakan bagian dari kegiatan Humas di suatu lembaga. Pemerintah sebagai bagian dari lembaga harus memiliki Humas dalam rangka menjaga kinerja dan citra yang baik bagi lembaga. Karena Humas merupakan salah satu elemen yang menentukan kelangsungan suatu organisasi secara positif (Sonia, 2013).

Universitas Padjadjaran (Unpad) sebagai salah satu institusi pendidikan perguruan tinggi negeri (PTN) yang di bawah pemerintah, memiliki capaian untuk menjadi Transformative University, dengan indikatornya memberikan kemaslahatan kepada masyarakat berdasarkan amanat tridarma perguruaan tinggi yakni pendidikan, penelitian dan pengabdian kepada masyarakat melalui penyampaian dan menghadirkan hasil pemikiran, ide, gagasan, dan karya yang solutif dari para pakar tenaga pendidik (dosen) untuk dapat memberikan solusi permasalahan publik, sebagai bagian dari fungsi edukasi yang menyandang Perguruan Tinggi Negeri yang Berbadan Hukum Milik Negara (PTN-BH) yang mempunyai otonomi dalam pengelolaan dan penyelenggaraan pendidikan.

Lahirnya program Unpad Merespon, berawal dari upaya untuk mencapai visimisi lembaga yang sangat membutuhkan kolaborasi dengan berbagai unsur, dalam bentuk penthahelix collaborations yang meliputi lembaga pemerintahan, media massa, industri/perusahaan, masyarakat (komunitas), dan akademisi. Atas dasar kebijakan pimpinan Unpad melalui program penthahelix collaborations tersebut, media massa menjadi salah satu unsur baru stakeholder Unpad yang tertera dalam pengembangan model kolaborasi stakeholders Unpad dengan menambahkan dua unsur baru yakni media massa dan komunitas yang sebelumnya hanya terdiri dari tiga unsur, akademisi, pemerintah dan pengusaha. Adapun 
bentuk kontribusi pemberian solusi terhadap permasalahan yang ada di masyarakat, Unpad menyelenggarakan suatu program yang disebut dengan Unpad Merespon, yang merupakan salah satu program Public Relations yang dilaksanakan oleh Direktorat Tata Kelola \& Komunikasi Publik, khususnya Bagian Hubungan Masyarakat dengan target sasarannya adalah media massa.

Terpilihnya media massa sebagai stakeholder Unpad, membuat Unpad harus memiliki sebuah program yang dapat menjalin hubungan baik antara Unpad dengan stakeholders ebagai bentuk keseriusan menjalin komunikasi yang baik yang membutuhkan eksistensi lembaga di pandangan publiknya. Sebagai bentuk implementasi dari media relations yang terbentuk adalah melalui pembuatan program media center yang khusus bekerjasama dengan media massa, yakni Program Unpad Merespon. Secara praktis program Unpad Merespon terbentuk yang merupakan salah satu cara yang ditempuh untuk mencapai tujuan Unpad sebagai transformative university yang berkontribusi mengenai berbagai macam ide dan gagasan solutif kepada masyarakat cepat tersampaikan dengan baik. Adapun tujuan lainnya dari program Unpad Merespon sebagai penciri transformative university adalah mewujudkan tatanan ide gagasan yang berdasarkan kajian ilmiah untuk dapat memberikan kemaslahatan dan dampak pembangunan positif kepada masyarakat, serta terjalinnya kerja sama interpedensi dengan berbagai pihak yang terkait dengan isu yang dibahas.

Adapun bentuk kerjasama Unpad dengan media massa, yakni Unpad menyampaikan informasi kepada publik terkait dengan fungsi edukasi bagi masyarakat dengan menyediakan berbagai kebutuhan informasi ilmiah yang dikemas dalam secara profesional untuk disampaikan melalui acara talk show mengenai isu kekinian dengan mengundang pihak media massa. Unpad menyadari bahwa sebagai lembaga pemerintahan, yang salah satu tuntutan dan keinginan publik kepada pemerintah di era teknologi informasi dan komunikasi (TIK) ini adalah keterbukaan dan transparansi informasi (Ristanto, 2014).

Pelaksanaan penyampaian informasi dan penyebaran informasi yang bersifat ilmiah dalam program Unpad Merespon, merupakan sebagai wujud harmonisasi kedua pihak dalam menjalankan chek and balance seputar informasi pendidikan suatu lembaga pemerintahan. Fungsi edukasi dilakukan dengan memberikan pandangan akademisi Unpad terhadap permasalahan yang ada di masyarakat sebagai solusi ataupun pertimbangan bagi pemangku kebijakan dalam membuat sebuah keputusan. Sedangkan pada media massa fungsi 
penginformasian publik, dilakukan dengan menghasilkan karya jurnalistik yang memenuhi kriteria cover both side yakni tulisan yang berimbang, objektif dan menghadirkan beberapa sudut pandang untuk menghasilkan tulisan yang komprehensif, yaitu dielaborasikan dengan pandangan akademisi dalam menanggapi sebuah isu di masyarakat sebagai sebuah fakta yang perlu untuk dicarikan solusinya secara arif dan bijaksana.

Program Unpad Merespon merupakan bagian dari upaya lembaga untuk memperkenalkan civitas akademika nya yang memiliki prestasi secara ilmiah kepada masyarakat sebagai bentuk tanggungjawab fungsi lembaga pendidikan. Melalui Unpad Merespon kekurangkenalan civitas akademika Unpad di kalangan media massa setidaknya dapat mengurangi permasalahan yang dihadapi oleh Unpad yang sedang menjalankan visi Transformative University. Hal ini terungkap sebagaimana yang disampaikan oleh Direktur Tata Kelola dan Komunikasi Publik;

Unpad memliki SDM (dosen) yang berkualitas yang sama bahkan lebih di beberapa bidang dari PTN lain, sayangnya belum diikuti dengan publikasi karya, sehingga apabila ada masalah publik, para ahli atau pakar yang dimunculkan oleh media, belum dari Unpad, padahal kita memiliki source yang berkualitas.

Kondisi tersebut, senada juga dengan apa yang disampaikan oleh salah satu pihak media massa. Menurut, Herik Kurniawan, koordinator News Program di Global TV mengatakan bahwa selama ini pihak media massa televisi khususnya, selalu mencari beberapa pakar perguruan tinggi untuk menjadi narasumber pada isu tertentu yang akan dibahas di topik pemberitaan dan kurangnya informasi direktori kepakaran ini acapkali membuat media mewawancarai beberapa tokoh yang sering tampil secara nasional. Sehingga, untuk menjadikan media sebagai saluran komunikasi dari Unpad kepada masyarakat terkendala pada pengetahuan wartawan terhadap bidang kepakaran Unpad. Sejalan dengan hal kondisi tersebut, dalam pembukaan acara Unpad Merespon pada tanggal 20 Oktober 2015, Rektor Unpad mengatakan bahwa;

Unpad memiliki publik yang luas, sedangkan Unpad hanya berada di satu titik, sehingga dibutuhkan saluran komunikasi yang dapat menjembati Unpad dengan publiknya, hal ini sejalan dengan fungsi media sebagai penginformasian kepada publik.

Keberadaan kegiatan media relations dalam sebuah instansi dapat menjadi penentu dalam keberlangsungan setiap aktivitas instansi. Sedangkan media relations sendiri merupakan taktik atau strategi public relations pada saat ingin mencapai tujuan dari kegiatan kehumasan itu sendiri (Hidayat, 2014). Dalam menjalankan kegiatan media relations, harus terdapat satu pemahaman yang sama antara 
lembaga dengan media massa bahwa keduanya adalah rekan kerja yang saling membutuhkan dan mendukung. Sehingga, tujuan dari kegiatan media relations, bukan sekedar memberikan informasi, tetapi juga terciptanya hubungan baik yang dapat membawa citra positif bagi instansi dan meningkatkan kualitas nilai berita pada media massa.

Berdasarkan observasi penelitian, Program Unpad Merespon memiliki beberapa keunikan. Pertama, sebagai kegiatan media relations dengan toolspress conference, biasanya dilakukan dengan tujuan untuk menanggulangi isu (management crisis) atau sebagai kegiatan launching produk atau jasa, namun press conference dalam Unpad Merespon tidak untuk keduanya, melainkan untuk menghadirkan Unpad ditengah-tengah masyarakat dan sebagai tempat yang dapat mempertemukan dosen dengan rekan-rekan media secara langsung. Kesamaan diantara Unpad Merespon dengan press conference pada umumnya adalah output yang diharapkan, yakni menjadi media publikasi Unpad dengan lebih efisien dapat dijangkau oleh masyarakat.

Efisien yang dimaksud salah satunya dari segi pendanaan, kegiatan ini lebih dapat menghemat anggaran publikasi dimedia, dibandingkan dengan cara beriklan. Selain itu, juga dapat membentuk sebuah relasi yang sifatnya informal dengan media, sehingga informasi dapat diberikan dengan lebih baik dan membangun hubungan emosional antara civitas akademika Unpad dengan wartawan media massa.

Kedua, biasanya pada kegiatan press conference dan tools press kit, yang dihadirkan kepada media adalah stakeholder tertinggi di instansi, yang memiliki kekuasaan tertinggi atau praktisi humas yang menjadi wakil institusi. Namun, dalam Unpad Merespon, fokus dalam melakukan branding stakeholder internal Unpad yang berada ditingkat "middle-up" yakni civitas akademika Unpad, tenaga pendidik Unpad. Dalam menentukan narasumber, kegiatan ini tidak menjadikan jabatan sebagai indikator utama dalam menghadirkan narasumber kepada media, melainkan pada karya dan kebutuhan publik akan karya tersebut.

Ketiga, kegiatan ini, menjadikan media sebagai publik utama, yang diharapkan dapat menjadi saluran komunikasi Unpad kepada stakeholder lain, baik pemerintah, komunitas, dan pengusaha, dengan good will Unpad dalam tujuannya untuk meretas masalah publik bersama-sama, dan Unpad sebagai sumber akademisinya. Media sebagai publik utama, dapat dilihat dari pemetaan Unpad dalam model Pentahelix lima unsur stakeholder Unpad. Dan keempat, informasi yang disampaikan bersifat keilmiahan. Hal tersebut untuk menunjukkan sisi riset dan pendidikan dari tridharma perguruan 
tinggi yang harus ditampilkan Unpad. Informasi yang bersifat keilmiahan ini menjadi tantangan tersendiri bagi civitas akademika Unpad dalam mengasah kemampuan komunikasinya dan menghadirkan hasil riset yang bersifat media friendly sehingga mampu menarik dan diterima oleh media massa dan masyarakat.

Namun, berdasarkan kebutuhan media akan informasi yang komprehensif, pada 2015 pemateri yang dihadirkan dalam program Unpad Merespon mengalami perkembangan, civitas akademika Unpad sebagai akademisi tidak lagi menjadi pemateri tunggal, dengan hadirnya unsur pegiat dan pelaku dalam Unpad Merespon sebagai pelengkap dan pembanding sisi akademik. Unsur pegiat dan pelaku juga merupakan unsur dalam penthahelix model Unpad, sehingga kriteria transformative university yakni terjalinnya hubungan interpedensi dengan berbagai pihak dapat dipertemukan melalui Unpad Merespon.

Berdasarkan pemaparan di atas, keunikan dalam program Unpad Merespon diharapkan mampu menjawab tantangan media massa dalam mengenal kepakaran Unpad dan bagaimana kemampuan Unpad dalam bertransformasi mengikuti perkembangan kebutuhan media massa. Pada akhirnya program Unpad Merespon diharapkan mampu menjadi jembatan hubungan baik antara Unpad dengan media massa. Sehingga diharapkan mampu menjawab permasalahan publik dengan bidang keilmuan Unpad dan mengoptimalkan media sebagai saluran komunikasinya. Untuk itu, peneliti tertarik untuk melakukan penelitian terhadap program Unpad Merespon sebagai upaya Unpad dalam menjalin hubungan baik dengan media massa.

Dengan demikian penelitian ini dilakukan dengan tujuan untuk mengetahui dan menjelaskan pola komunikasi two asymetrical dalam kegiatan media relations yang dilakukan oleh Universitas Padjadjaran pada program Unpad Merespon.

\section{METODE PENELITIAN}

Dalam penelitian ini, yang menjadi subjek penelitian adalah pimpinan dan atau dosen yang terkait dengan penyampaian informasiyang disampaikan oleh Direktorat Tata Kelola dan Komunikasi Publik. Adapun objek penelitiannya adalah penyampaian informasipada Program Unpad Merespon.

Secara ilmiah, subjek penelitian adalah sumber data yang dimintai informasinya sesuai dengan masalah dalam penelitian. Subjek penelitian tersebut diharapkan dapat menjadi representasi dari suatu kelompok atau entitas (Saebeni \& Ahmad, 2012). Untuk mendapat data yang tepat maka perlu ditemukan informan yang memiliki kompetensi dan sesuai dengan kebutuhan data (purposive). 
Paradigma yang digunakan dalam penelitian ini adalah paradigma positivisme, Sehingga metode penelitian yang digunakan adalah metode deskriptif dengan penyajian data kualitatif. Pendekatan kualitatif menurut Pujileksono, dipergunakan untuk menemukan atau mengembangkan teori yang sudah ada (Pujileksono, 2016). Sedangkan Suryabrata, menyebutkan bahwa tujuan penelitian deskriptif adalah fakta-fakta dan sifatsifat populasi yang ada di daerah tertentu dipergunakan secara sistematis, faktual, dan akurat sebagai sebuah hasil penelitian yang ada di masyarakat (Suryabrata, 1998). Metode deskriptif menekankan pada observasi dan suasana ilmiah yang apa adanya. Peneliti hanya bertindak sebagai pengamat dan hanya membuat kategori pelaku, mengamati gejala kemudian mencatatnya. Metode deskriptif adalah metode yang digunakan sebagai studi penjajakan suatu fenomena dengan menyajikan satu gambar yang terperinci tentang satu situasi khusus, setting sosial, atau hubungan.

Teknik penentuan key informant dalam penelitian ini menggunakan teknik purposive sampling dengan kriteria yakni civitas akademika Unpad, telah bergabung dalam kegiatan Unpad Merespon minimal tiga bulan, memiliki hak suara dalam menentukan kebijakan pelaksanaan Unpad Merespon. yakni dengan tujuh orang dari direktorat tata kelola dan komunikasi publik Unpad.Teknik pengumpulan data yang dilakukan dengan cara teknik wawancara mendalam, observasi partisipatif, studi pustaka dan dokumen. Teknik analisis data yang digunakan yakni dengan pengumpulan data, reduksi data, penyajian data dan penarikan kesimpulan.Teknik keabsahan yang digunakan adalah tringulasi dengan dua orang wartawan dari Binis Indonesia dan Pikiran Rakyat.

\section{HASIL DAN PEMBAHASAN}

Program Unpad Merespon dibahas menjadi empat bagian berdasarkan prosesnya yakni, latar belakang program Unpad Merespon, perencanaan program Unpad Merespon, pelaksanaan program Unpad Merespon, dan evaluasi program Unpad Merespon.

Perumusan masalah pada program unpad merespon. Latar belakang program Unpad Merespon dilaksanakan oleh Direktorat Tata Kelola dan Komunikasi Publik adalah terdiri atas tiga alasan, pertama, yakni adanya perubahan struktural terhadap peta stakeholder Unpad berdasarkan kebijakan rektor Unpad. Kedua, sebagai salah satu cara untuk mewujudkan misi Unpad dalam menjadikan Unpad sebagai universitas yang bermaslahat bagi masyarakat melalui publikasi kepakaran civitas akademika Unpad, dan ketiga, kebutuhan civitas akademika Unpad untuk hadir di masyarakat melalui 
media massa dan kebutuhan media massa akan berita yang harus dipenuhi oleh Unpad sebagai lembaga pendidikan dan research. Pada tahap perumusan masalah ini, Unpad selaku instansi pendidikan dan pihak jurnalis (wartawan) media sebagai perwakilan media massa, harus memiliki pemahaman yang sama terhadap masing-masing fungsinya sehingga terjalin komunikasi dua arah yang bersifat timbal balik. Komunikasi dua arah ini pada dasarnya sebagai sebuah fungsi komunikasi yang berkaitan dengan cara membangun dan memelihara saling pengertian dan good will dari suatu organisasi/ lembaga dengan publiknya (Wiratmo, 2017).

Hal tersebut yang terkait dengan perencanaan program Unpad Merespon ini merupakan bagian dari peluang masyarakat untuk mengetahui kegiatan pada lembaga pemerintahan yang dengan sengaja memasukkan informasi untuk dipilih menjadi berita di media massa, yakni berupa Rubrik Khusus atau Headline pemberitaan (Belinda, 2016). Melalui perencanaan yang tersistematis dan disengaja merupakan capaian yang dapat dipertanggungjawabkan untuk mendapatkan hasil kegiatan secara optimal, khususnya informasi ilmiah yang terkait dengan isu tersampaikan ke masyarakat melalui media massa. Maka dari itu, mengenai perencanaan program Unpad Merespon dapat dibagankan sebagai berikut: Perencanaan pada Program

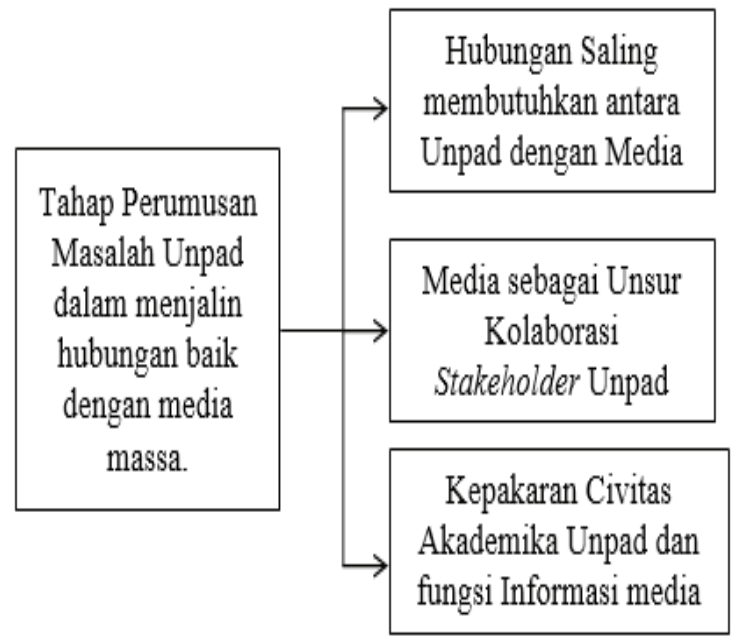

Sumber: Data Penelitian, 2016

\section{Gambar 1 Rumusan Masalah Program Unpad Merespon}

Unpad Merespon.

Pada tahap kedua berupa perencanaan program Unpad Merespon terdapat beberapa kegiatan, yakni: 1) Tahap pertama, yaitu penentuan tema. Pada tahap penentuan tema, yang menentukan tema adalah ketua pelaksanan program, direktur, dan pimpinan Unpad (rektor beserta wakil rektor). Dalam proses penentuan tema dilakukan dengan dua mekanisme, yaitu melakukan survei ketertarikan masyarakat dan menjawab aspirasi wartawan yang mengusulkan tema, kedua hasil penentuan tema tersebut dipertimbangkan dengan melihat ketersediaan kepakaran dosen yang ada di Unpad. 2) Tahap kedua adalah penetuan pemateri dengan kriteria dari tim Program Unpad Merespon yang meliputi merupakan civitas akademika Unpad, memiliki bidang kekhususan yang sesuai dengan keilmuan yang dikuasai yang sesuai dengan 
tema yang akan disampaikan, komunikatif, dan media friendly. 3) Tahap ketiga, adalah pemetaan media massa, pada tahap ini, media massa yang menjadi target utama adalah media massa yang memiliki rubrik pendidikan. Dari data internal bidang humas Unpad terdapat 32 kontak wartawan aktif yang terhimpun dalam sebuah group whatsaap untuk memudahkan komunikasi dan sebagai sarana penyebaran informasi lembaga ke kalangan jurnalis. Media tersebut terdiri dari media lokal hingga nasional, media elektronik, dan media cetak. 4) Tahap keempat, adalah tahapan publikasi bidang humas Unpad membagi segmentasi peserta program Unpad Merespon menjadi media massa, komunitas yang memiliki pembahasan sejalan dengan tema, dan civitas akademika Unpad yang terdiri dari mahasiswa program pascasarjana dan sarjana yang diwakili oleh lembaga kemahasiswaan; dan 5) Tahap kelima, adalah pembagian tugas berupa implementasi kegiatan. Pada tahap ini, pimpinan Direktorat Tata Kelola dan Komunikasi Publik bersama kepala pelaksana program Unpad Merespon, membagi tugas pelaksanaan penyelenggaran program Unpad Merespon kepada staf Humas sebagai tim teknis agar terselenggara dengan baik. Pembagian tugas program Unpad Merespon dipetakan berdasarkan kegiatan sehari-hari staf Humas Universitas, sehingga secara legalitas formal hal tersebut tidak

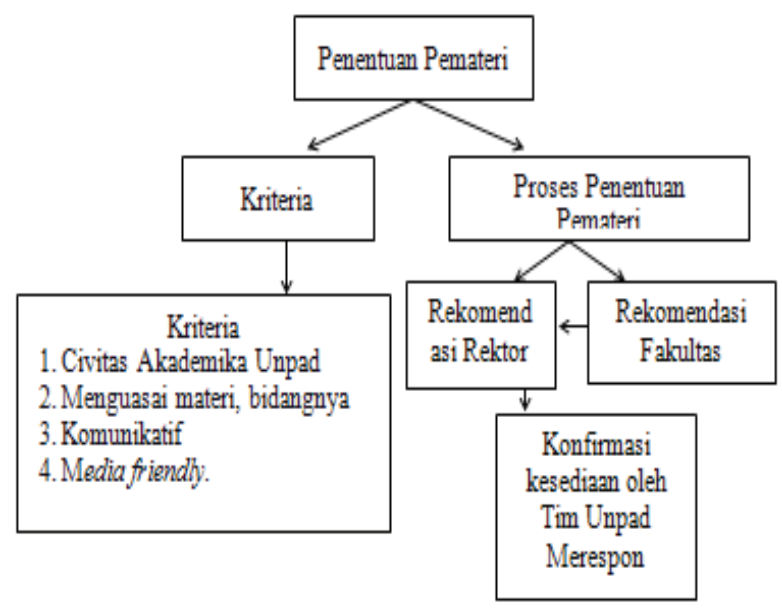

Sumber: Data Penelitian, 2016

\section{Gambar 2 Penentuan Pemateri}

terdapat dalam struktur pelaksanaan mengenai kegiatan Unpad Merespon.

Kelima tahapan pada proses perencanaan program Unpad Merespon merupakan bagian dari program proses humas suatu organisasi dalam rangka untuk mendapatkan kualitas komunikasi yang baik, terstruktur, sistematis dan kredibel. Maka, terkait dengan pemilihan tema beserta narasumber yang terpilihnya dalam program Unpad Merespon sesuai dengan apa yang dinyatakan oleh (Luqman, 2013) bahwa peran humas sangat penting dalam dalam memfasilitasi manajemen untuk melakukan proses komunikasi yang bersifat dinamis, dimana informasi dengan tema tertentu dipertukarkan secara dua arah antara pihak manajemen dengan para stakeholdernya. Untuk tahap perencanaan program Unpad Merespon, peneliti membahasnya dengan menggunakan model perencanaan kisi-kisi, 
yang dimana pada perencanaan strategis, terdapat 10 pertanyaan yang terbagi menjadi tiga bagian, yaitupertama, identifikasi khalayak dan tujuan, pada tahap ini semua pertanyaan dapat dijawab oleh narasumber dalam program Unpad Merespon. Kedua, melaporkan temuan penelitian, pada tahap ini pertanyaan dari pihak wartawan hanya akan dijawab dengan menggunakan sudut pandang tim Unpad Merespon, sedangkan pertanyaannya adalah berkaitan dengan kebutuhan khalayak segmentasi, dan pada bagian ketiga mengenai penilaian dan pengembangan rencana pertanyaan mampu dijawab sesuai kebutuhan program Unpad Merespon terkait tema atau isu yang ada di masyarakat.

Pada tahap perencanaan taktis, pertanyaan mengenai rencana jangka pendek-panjang yang ada pada program Unpad Merespon, tidak terjawab dengan baik. Hal inidikarenakan pada program Unpad Merespon sedang berjalan dilakukan tanpa indikator yang berjangka. Dari sepuluh pertanyaan pada model perencanaan strategis dan lima pertanyaan pada model perencanaan taktis program Unpad Merespon, didapatkan hasil bahwa pada proses perencanaan sudut pandang yang digunakan adalah sudut pandang penyelenggara kegiatan, tanpa menyertakan sudut pandang media massa sebagai publik sasaran, sehingga pada pelaksanaan teknis target jumlah kehadiran media massa tidak terukur. Padahal, secara manajemen danteknis, stafhumas suatulembaga/ organisasi harus mampu melaksanakannya terkait dengan kemampuan mengidentifikasi isu dan masalah (expert prescriber), membantu pimpinan memecahkan masalah (problem solving) dan memfasilitasi komunikasi dua arah yang timbal balik (communication facilitator). Implementasi Program Unpad Merespon.

Pada tahap ini peneliti menguraikan proses implementasi program Unpad Merespon, terdiri dari serangkaian kegiatan antara lain adalah; a) Tahap komunikasi dan koordinasi, berikut adalah alur komunikasi dan koordinasi: (b) Tahap Aksi (Pelaksanaan) dilakukan dengan pelaksanaan pembagian tugas yang sudah disepakati di tahap perecanaan strategis. Masing-masing staff menjalankan fungsinya dalam pengawasan pimpinan; c) Teknik Penyampaian Pesan. Proses penyampaian pesan dalam program Unpad Merespon, Pada

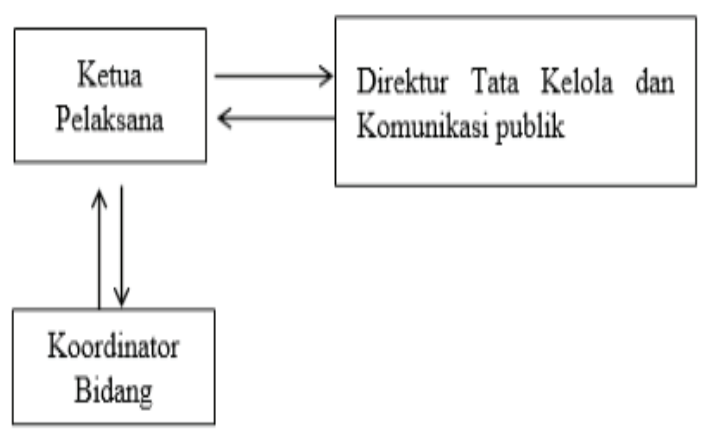

Sumber: Data Penelitian, 2016

Gambar 3 Alur Komunikasi dan Koordinasi dalam tahap Implementasi 


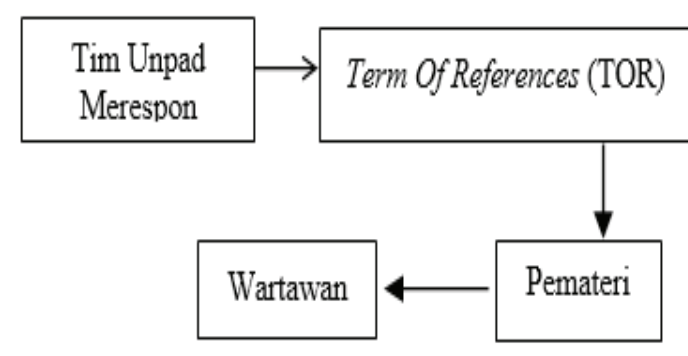

Sumber: Data Penelitian, 2016

\section{Gambar 4 Teknik Penyampaian Pesan}

gambar 4, menunjukkan bahwa penyampaian pesan dilakukan secara tidak langsung dari tim Unpad Merespon kepada wartawan yakni melalui pemateri sebagai saluran komunikasi. Guna mendapatkan hasil pelaksanaan program Unpad Merespon yang berkualitas ada beberapa hal yang perlu dilaksanakan yaitu adanya tahapanbpengawasan yang dilakukan oleh ketua pelaksana Unpad Merespon dan Direktur yang tertera dalam kerangka acuan kerja (KAK) yang sesuai dengan cara bertanya dan memastikan komponen kegiatan apakah berjalan dengan baik atau tidak. Selanjutnya, terkait dengan tahapan kendala dan cara mengatasinya. Apabila terjadi kendala dalam pelaksanaan, staff yang bertugas akan segera mencari solusi untuk mengatasinya yang dibantu oleh ketua pelaksana selaku pemegang kebijakan setelah pimpinan manajemen. Pada pelaksanaan program Unpad Merespon ada kendala yang terjadi seperti apabila ada salah satu pembicara melakukan konfirmasi tidak hadir pada saat acara akan dimulai, maka cara mengatasinya adalah dengan meminta rekomendasi nama atau memberikan informasi kepada peserta bahwa pembicara berhalangan hadir. Penyelesaian pada tahapan ini seperti kendala teknis pada program Unpad Merespon tidak dibuku dalam sebuah panduan SOP, sehingga apabila terjadi kendala dilapangan dapat diatasi berdasarkan pengalaman sebelumnya. Artinya, pelaksanaan program Unpad Merespon merupakan bagian dari media relations yang sedang dikembangkan oleh Direktorat Tata Kelola dan Komunikasi Publik Universitas Padjadjaran. Media relations sebagai strategi dari pekerjaan Humas suatu lembaga harus dapat memahami terlebih dahulu mengenai kedudukan media dan media relations itu sendiri (Hidayat, 2014).

Dalam membahas tahap implementasi, peneliti menggunakan konsep 7C PR dari (Cutlip, Center, \& Bloom, 2006), yang terdiri dari credibility, context, content, clarity, continuity \& consistency, cannel, dan capabality of the audience. Prinsip pertama yang terdapat dalam program Unpad Merespon adalah credibilty dalam menetapkan pemateri, tim Unpad Merespon akan meminta rekomendasi dari pimpinan fakultas yang ada di Unpad, sehingga pemateri yang hadir adalah pemateri yang sudah teruji dan hasil rekomendasi. Selain itu, kredibilitas suatu kegiatan juga dibangun atas dasar pengkondisian tempat 
pelaksaan dan suasana yang dirasakan oleh komunikan (wartawan). Pelaksanaan program Unpad Merespon dilakukan dikampus Unpad yang bertempat di Jalan Dipati Ukur. Hal ini dilakukan dengan pertimbangan bahwa pihak wartawan akan mempertimbangkan aksesbilitas danj arak lokasi tempat yang strategis ditengah kota Bandung.

Sebagai bentuk membangun kredibilitas penyajian program Unpad Merespon yang berkualitas, pemilihan ruang kegiatan menjadi faktor utama, yakni di ruang Excutive Lounge. Ruangan Executive Lounge merupakan suatu yang sengaja didesign sebagai ruang diskusi yang nyaman dan memiliki kesan executive. Pemilihan tempat dan ruang ini menunjukkan keseriusan Unpad dalam menjamu wartawan dari berbagai media massa yang diharapkan mampu meningkatkan nilai kredibiltas penyelenggaraan dan membuat media massa semakin percaya pada Unpad. Mengenai prinsip konteks dan konten pada program Unpad Merespon dapat dilihat dari kegiatan cara merencanakan dan memilih tema yang diangkat, pemilihan konteks dan konten tema tersendiri yang memiliki kriteria atau indikator khusus untuk mengangkat sebuah isu publik menjadi tema dalam kegiatan Unpad Merespon. Pertimbangan tersebut berdasarkan kebutuhan publik, dan media massa, sehingga kegiatan Unpad Merespon dapat berjalan sesuai konteks dan kontennya yang dapat diterima oleh publik dan media massa. Prinsip clarity atau kejelasan, tidak dilakukan oleh tim Unpad Merespon langsung kepada wartawan, karena proses komunikasi dalam Unpad Merespon pada saat diskusi adalah dari tim Unpad Merespon kepada pemateri dan dari pemateri kepada wartawan. Namun, hal ini juga menjadi perhatian tim Unpad Merespon, sehingga kejelasan pesan disampaikan kepada pemateri melalui TOR yang diharapkan menjadi panduan, dan batasan pemateri dalam menyampaikan materi.

Prinsip selanjutnya dalam pertimbangan tahap implementasi adalah continuity \& consistency berkelanjutan dan konsisten. Salah satu latar belakang dan kebutuhan media massa dalam upaya menjalin hubungan baik adalah adanya komunikasi yang berkelanjutan dan kosisten. Dimana komunikasi merupakan sebuah proses tanpa akhir, sehingga dalam menjalankannya dibutuhkan repitisi (pengulangan) dan variasi.

Adanya permintaan media massa untuk berdiskusi dengan pakar Unpad dan kebutuhan media untuk mendapatkan informasi yang bersifat cover both side dengan sudut pandang keilmiahan, melahirkan inisiasi untuk membuat program komunikasi dengan media massa yang bersifat rutin. Program Unpad Merespon dilakukan dengan intensitas satu bulan satu kali. Adapun channel, saluran komunikasi 
adalah penentu dari penerimaan publik. Saluran komunikasi yang sesuai dengan publik, akan memudahkan proses komunikasi. Saluran komunikasi yang digunakan tim Unpad Merespon adalah media sosial yakni surat elektronik yang ditujukan pada media massa sebagai lembaga dan wartawan sebagai perseorangan. Kemudian berkembang, menggunakan media sosial, Website, Twitter. Kemudian berkembang lagi, menggunakan media dengan pendekatan interpersonal, yakni melalui aplikasi multichat Whatsaap.

Terakhir yakni pertimbangan capability of audience. Pertimbangan ini tidak dilakukan secara langsung oleh tim Unpad Merespon. Hal initerjadikarenapenyampaianpesan sepenuhnya dilakukan oleh pemateri. Namun, salah satu pertimbangan dalam pemilihan pemateri adalah kemampuan komunikasi pemateri dalam menyampaikan temuan ilmiahnya dengan menggunakan bahasa yang media friendly. Melalui kriteria tersebut, pematerilah yang diharapkan dapat mempertimbangkan kemampuan khalayak dalam menerima pesan.

Berdasarkan prinsip 7C yang dijadikan sebagai bahan pertimbangan dalam implementasi bertujuan untuk memudahkan praktisi PR mengimplementasikan berbagai program PR. Terkait dalam pelaksanaan program Unpad Merespon, proses implementasi sudah dilakukan berdasarkan beberapa pertimbangan mengenai prinsip 7C yakni, credibility, context, content, continuity, dan channel. Sejalan dengan prinsip 7C, triangulator peneliti, yakni Ibu Agne dari media Bisnis Indonesia menyampaikan beberapa pertimbangan untuk menghadiri kegiatan Unpad Merespon, yakni a) Tema yang dibahas apakah berkenaan dengan Contexts dan Contentsisu yang ada di masyarakat atau tidak; b) Narasumber yang dihadirkan apakah kredibel atau tidak; c) Jenis informasi dari narasumber yang datang ada yang bisa dikembangkan atau tidak, baik dari perspektif isu itu sendiri atau tema lain yang sedang hangat yang terkait dengan kepakaran narasumber; dan d) terkait dengan narasumber dari luar Unpad, adakah kemungkinan untuk dapat membangun jejaring dalam hal peningkatan prestasi lembaga atau tidak. Kehadiran wartawan dalam kegiatan Unpad Merespon adalah bentuk dari perencanaan strategis, yang menjawab target jangka pendek dari program PR. Kehadiran wartawan sangat menentukan keberhasilan dan efektivitas program. Sehingga hal-hal diatas harus dipertimbangkan dalam tahap implementasi untuk mencapai tujuan instansi.

Kegiatan evaluasi dalam program Unpad Merespon dilakukan dengan dua cara, yakni melalui evaluasi kegiatan yang dilakukan saat akan memulai kembali kegiatan dan melalui kegiatan media monitoring.

Dalam program Unpad Merespon kegiatan 


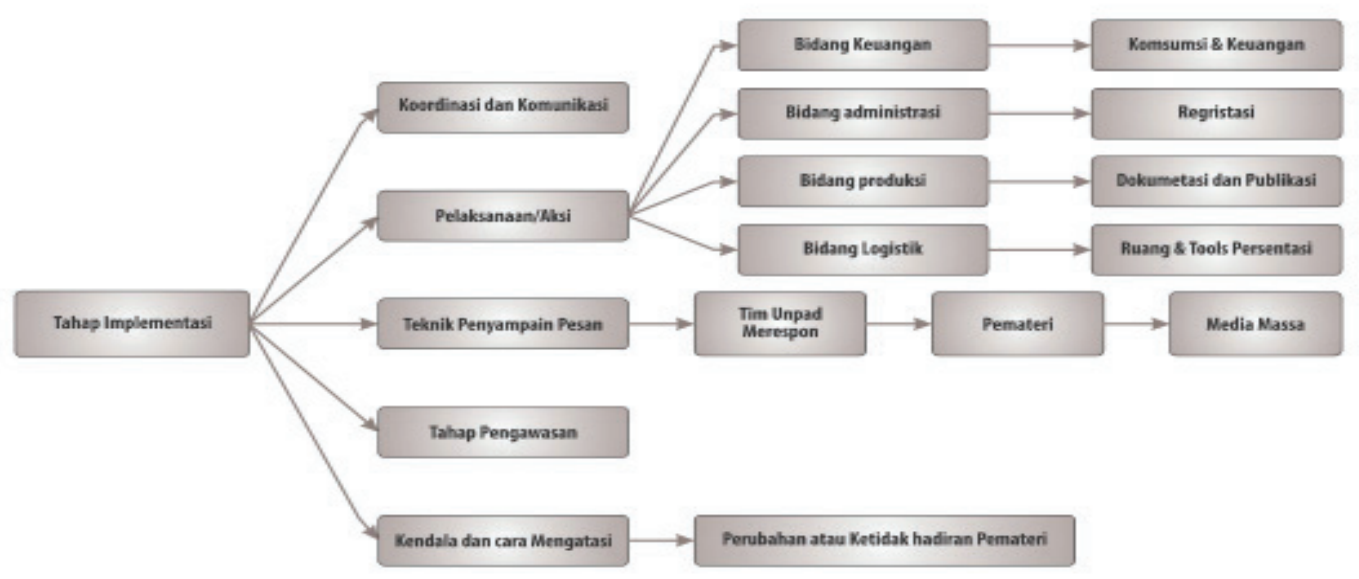

Sumber: Data Penelitian, 2016

\section{Gambar 5 Implementasi Program Unpad Merespon}

evaluasi dilakukan untuk melihat sejauhmana pengaruh dari pelaksanaan program Unpad Merespon dalam mengangkat sebuah isu dan sebagai kegiatan dokumentasi. Untuk melihat hasil dari suatu kegiatan humas suatu lembaga, (Cutlip et al., 2006) mengemukakan tiga tingkat dan tahap evaluasi yakni preparation evaluation, implementation evaluation dan impact evaluation, untuk tahap preparation evaluation tidak ada kegiatan yang menggambarkan bahwa program Unpad Merespon melakukan evaluasi pada tahap persiapan. Sedangkan pada tahap implementation evaluation kegiatan pendokumentasian dari seluruh materi komunikasi yang telah diproduksi dan disebarkan dilakukan pada saat pembuatan laporan pertanggung jawaban (LPJ) kegiatan, sehingga evaluasi implementasi dilakukan dalam bentuk laporan yang mendeskripsikan pelaksanaan program Unpad Merespon. LPJ dibuat setiap selesai pelaksanaan kegiatan, dan dalam evaluasi program tahunan dalam LPJ akhir tahun, bersamaan dengan keseluruhan program humas yang telah dilakukan dalam kurung waktu satu tahun.

Terakhir, adalah tahap impact evaluation dilakukan untuk melihat apakah pelaksanan kegiatan humas sudah sesuai dengan tujuan atau belum. Dalam program Unpad Merespon, evaluasi untuk melihat sejauhmana pengaruh dari kegiatan yang sudah dilakukan, ditinjau dengan melihat jumlah kuantitas berita yang terbit dari kegiatan Unpad Merespon yang didapatkan dengan cara media monitoring 
berupa kliping berita-berita yang publis di media massa yang diundang.

Kegiatan Media monitoring ini merupakan agenda kegiatan rutin humas Unpad untuk mengetahui posisi citra Unpad di masyarakat. Biasanya saat akhir tahun, dalam laporan pertanggung jawaban program hasil karya media massa yang menuliskan berita dari hasil Unpad Merespon akan dirangkumkan untuk menjadi bagian capaian kinerja bagian humas universitas. Kliping media dilakukan di sub bagian humas yaitu oleh dua orang staf humas, dimana satu orang memonitor dari media cetak, dan satu orang memonitor melalui media elektronik. Kegiatan klipping media yang terkait dengan program Unpad Merespon dilakukan untuk meninjau pengaruh kegiatan Unpad Merespon terhadap kuantitas publikasi pakar dan kegiatan Unpad di media massa, sehingga belum ada pengukuran atau indikator sebuah kegiatan dapat dikatakan berhasil atau tidak yang berdasarkan pada sebuah konsep atau teori.

Keberhasilan suatu kegiatan humas selalu dapat diukur dan ada indikatornya. Pada program Unpad Merespon, keberhasilan suatu kegiatan humas antara lain dapat diukur dengan melakukan wawancara mendalam, observasi dan membaca dokumen dari laporan pertanggung jawaban program Unpad Merespon. Jefkins, menjelaskan beberapa metode pengukuran keberhasilan suatu kegiatan humas yakni melalui liputan pers, pengumpulan pendapat, dan pengukuran berdasarkan hasil-hasil yang diinginkan (Jefkins, 2004).

Pengukuran dengan pengumpulan pendapat juga dilakukan dalam program Unpad Merespon, hal ini dilakukan oleh Bapak Soni selaku direktur tata kelola dan komunikasi publik Unpad, dan Ibu Gantini selaku kepala divisi layanan informasi. Pengumpulan pendapat dilakukan setelah acara selesai, melalui obrolan informal, mengenai pengalaman dan pendapat wartawan yang hadir dalam program Unpad Merespon. Dari pengumpulan pendapat ini didapat hasil, bahwa media massa yang memiliki rubrik pendidikan juga membutuhkan program rutin yang dapat membahas suatu isu yang membutuhkan unsur akademisi. Hal tersebut juga didukung dengan pernyataan Ibu Agne sebagai triangulator dalam penelitian ini.

Menurut ibu Agne,

Saya merasakan manfaatnya, pas awal saya jadi kontributor di Bisnis Indonesia, ketika itu langsung di desk pendidikan, melalui Unpad Merespon ini saya jadi tahu dengan humas nya Unpad, bisa terjalin hubungan yang baik, ketika ada perlu tentang isu atau sebuah berita, bisa ditanyakan ke humasnya. Jadi sangat baik menurut saya, apalagi kadang-kadang dalam sebuah isu, kita butuh statment dari pakar yang memang ahli dibidangnya, dan disini Unpad memiliki pakar atau ahli yang bisa memberikan informasi tersebut.

Jumlah publikasi di media massa, 
dipengaruhi oleh penilaian media terhadap suatu isu untuk diangkat menjadi tulisan terbit dimedia massa. Menurut Ibu Agne dan Ibu Dewi, berikut adalah hal-hal yang menjadi pertimbangan wartawan khususnya mereka dalam mempublikasikan hasil dari kegiatan Unpad Merespon, yakni 1) Nilai berita yang berupa kelengkapan narasumber; seberapa kuat beritanya; materi/bahan beritanya lengkap atau tidak; komprehensif atau tidak; dan aktualitas atau kekinian isu berita.

Pola Hubungan Two Ways Asymmetrical pada kegiatan Hubungan Media pada Program Unpad Merespon

Berdasarakan hasil penelitian diatas, maka kebutuhan Unpad dan Media adalah hubungan yang saling mengisi dan saling menguntungkan sesuai dengan pola hubungan stakeholder PR dengan model Two Ways Asymmetrical (Grunig, 2012). Walaupun harmonisasi hubungan antara humas dan pers merupakan suatu keharusan tetapi tidak selalu berjalan mulus. Ada kalanya pers merasa hubungannya dirugikan akibat adanya informasi yang tidak baik yang ditudingkan keluar dari seorang humas atau malah sebaliknya (Hidayat, 2014). Realitas media relations dalam program Unpad Merespon dapat digambarkan sebagai berikut: Kegiatan Unpad Merespon, dianggap sebagai hal yang bermanfaat dan menguntungkan bagi media massa, karena adanya kesadaran diantara

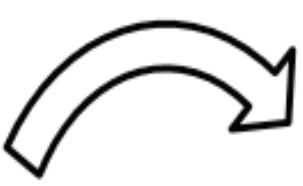

Civitas

Akademi Wartawan ka Unpad

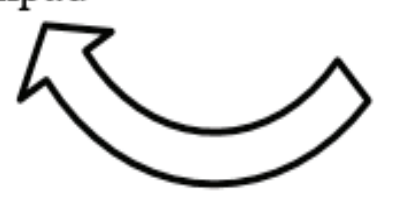

Sumber : Data Penelitian, 2016

Gambar 6 Pola Hubungan Two Ways Asymmtrical Unpad dan Media Massa pada program Unpad Merespon

keduanya dan juga kerjasama yang baik. Kedekatan interpersonal dan sikap proaktif juga menjadi hal penting dalam menjalin hubungan baik dengan media massa, seperti yang dilakukan oleh Ibu Gantini selaku kepada divisi pelayanan informasi dan ketua pelaksana Unpad Merespon yang melakukan komunikasi interpersonal dengan menghadirkan grup Whatsaap sebagai saluran komunikasinya. Dengan demikian pola hubungan two ways asymmetrical menjadi pola yang sesuai dalam menjalin hubungan baik antara instansi dengan stakeholder-nya dalam kegiatan hubungan media.

\section{SIMPULAN}

Tahap perumusan masalah dalam program Unpad Merespons merupakan langkah awal dalam menjalankan dan mengembangkan civitas akademika Unpad untuk dikenal di masyarakat. Hal ini diperkuat dengan kebutuhan yang 
terdapat dalam Unpad Merespon, mencakup kebutuhan media massa akan informasi bidang keilmiahan dan pendidikan, media massa sebagai salah satu unsur kolaborasi stakeholder Unpad dan kebutuhan publikasi keparakan Unpad di media massa.

Tahap perencanaan dalam program Unpad Merespon merupakan tahap penyusunan strategi komunikasi untuk mencapai tujuan dan menjawab kebutuhan isu yang terjadi di masyarakat. Di mana dalam tahap perencanaan dibutuhkan tahapan penentuan tema, pemateri, pemetaan media massa, publikasi kegiatan dan pembagian tugas untuk tahap aksi.

Tahap implementasi dalam program Unpad Merespon adalah suatu rangkaian proses dalam mengimplementasikan perencanaan yang meliputi kegiatan komunikasi dan koordinasi, aksi, teknik penyampaian pesan, tahap pengawasan dan kendala serta cara mengatasinya.

Tahap evaluasi dalam program Unpad Merespon dilakukan saat akan memulai kembali kegiatan Unpad Merespon, dan melalui kegiatan media monitoring dengan kliping media.

\section{DAFTAR PUSTAKA}

Belinda, S. (2016). Peran humas pemerintah sebagai fasilitator komunikasi pada biro humas pemprov Kalimantan Selatan. Jurnal Penelitian Komunikasi, 19(1), 5568.

Cutlip, Center, \& Bloom. (2006). Effective public relations. Jakarta: Kencana.

Grunig. (2012). Model hubungan pr dengan stakeholder. in $r$. darmastuti, media relations - konsep, strategi dan aplikasi. Yogyakarta: Andi Offshet.

Hidayat, D. (2014). Media public relations:pendekatan studi kasus cyber public relations sebagai metode kerja $P R$ digital. Bogor: Graha Ilmu.

Jefkins, F. (2004). Public relations. Jakarta: Gelora Aksara Partama.

Luqman, Y. (2013). Peran dan posisi hubungan masyarakat sebagai fungsi manajemen perguruan tinggi di Semarang. Jurnal Interaksi, 2(1), 1-10.

Pujileksono. (2016). Metode penelitian komunikasi kualitatif. Malang: Instran Publishing.

Ristanto, T.(2014). Peran humas pemerintah kota Balikpapan dalam mengimplementasikan konsep smart city di kota Balikpapan. Commonline Departemen Komunikasi, 4(1), 387-399.

Saebeni, A. \& Ahmad, B. (2012). Metodologi penelitian kualitatif. Bandung: Pustaka Setia.

Sonia, G. (2013). Aktivitas humas badan layanan umum (BLU) Dalam Mensosialisasikan Trans Jakarta . Jurnal Visi Komunikasi. XII (02), 276-291.

Suryabrata, S. (1998). Metodologi penelitian. Jakarta: Raja Grafindo Persada.

Wiratmo. (2017). Website pemerintah daerah sebagai sarana online public relations. Jurnal ASPIKOM, 3(2), 326. 